\title{
Studies on Combined Application of Organic and Inorganic Amendments on Micronutrients Availability to Turmeric in an Acid Alfisol
}

\author{
Shubham $^{1 *}$, S.P. Dixit ${ }^{1}$ and P. Pathania ${ }^{2}$ \\ ${ }^{1}$ Department of Soil Science, ${ }^{2}$ Department of Agronomy, CSK Himachal Pradesh Krishi \\ Vishvavidaylaya, Palampur 176062 (H.P.) India \\ *Corresponding author
}

\section{A B S T R A C T}

\section{Keywords}

Turmeric, micronutrient, Rhizome yield, STCR, Nutrient management

Article Info

Accepted: 04 September 2020 Available Online: 10 October 2020
This study aimed to assess the effectiveness of different fertilizers doses with organic manures on micronutrients availability in turmeric (Curcuma longa L.). A field experiment in completely randomized block design was conducted with eight treatments which were replicated thrice. The eight treatments were comprised of four soil test crop response based treatments along with farmer's practice, general fertilizer dose, soil test based and absolute control. Results of the study showed that STCR based treatment of targeted yield $40 \mathrm{tha}^{-1}$ documented highest concentrations of micronutrients viz. Fe $\left(21.23 \mathrm{mg} \mathrm{kg}^{-1}\right), \mathrm{Mn}(18.58$ $\left.\mathrm{mg} \mathrm{kg}{ }^{-1}\right), \mathrm{Zn}\left(0.83 \mathrm{mg} \mathrm{kg}^{-1}\right)$ and $\mathrm{Cu}\left(0.62 \mathrm{mg} \mathrm{kg}^{-1}\right)$ in soil. Moreover, similar treatment also recorded highest concentrations of micronutrients in turmeric rhizome and straw. Regarding the micronutrient uptake, highest values of uptake were associated with the targeted yield treatment of 40 tha $^{-1}$ i.e. Fe, $\mathrm{Mn}, \mathrm{Zn}$ and $\mathrm{Cu}$ uptake in rhizome $(1414,696$, 564 and $629 \mathrm{~g} \mathrm{ha}^{-1}$, respectively) while in straw $\left(84.5,77,65.6\right.$ and $78.5 \mathrm{~g} \mathrm{ha}^{-1}$, respectively). Higher concentrations and uptake of micronutrients at the harvest of crop advocated the superiority of STCR over the traditional fertilization approaches. The study concluded that the practice of STCR could be recommended to turmeric grown under Alfisol.

\section{Introduction}

Turmeric (Curcuma longa L.) a herbaceous perennial medicinal plant belongs to family Zingiberaceae and sub-family Zinigeradeae. It is most sacred and ancient spice of India commonly known as Indian saffron and golden spice of life. Being a tall annual herb it requires considerable amount of rainfall and temperature between 20 and $30^{\circ} \mathrm{C}$ to thrive well. Cultivation of this spice crop can be practiced from sea level to an altitude of 1500 $\mathrm{m}$, establish well in a $\mathrm{pH}$ range of 4.5 to 7.5 (Anonymous, 2013). It develops as a large ovoid root stock that bears stalkless cylindrical tubes with distinct orange color. Rhizomes can be considered as underground stems having roots below and leaves growing above the surface. Due to its shallow rooting, it requires heavy nutrients application and has a capacity to produce large amount of dry matter per unit area. It contains 5 per cent phenolic curcuminiods (diarylheptanoids) which are responsible for imparting the 
specific yellow colour to the rhizomes (Anonymous 2015). It also contains Carbohydrates $(69.4 \%)$, fats $(5.1 \%)$, proteins $(6.3 \%)$, minerals $(3.5 \%)$, volatile oil (5.0$6.0 \%)$ and oleoresin (7.9-10.4\%) (Srinivasan et al., 2016). Moreover, this spice has important role in preparing culinary curry dishes. Turmeric is certified as a natural food colour and has several uses in traditional Indian as well as modern medicines for various human ailments (Ravindran et al., 2007, Kumar and Ghosh, 2017). It is important in curing various diseases such as stomach disorders, fever, dropsy, ulcer and also consumed as blood purifier (Kanwar, 2000).

In India cultivation of this spice crop is practiced on commercial scale. India is the largest producer of turmeric around the globe and fulfilling 94\% of the world's demand. It occupies an area of 193.40 thousand hectares in the country with production of 1052.10 thousand tonnes annually which dominates the world production scenario contributing to $75 \%$ of world's total production (National Horticulture Board, 2017). Though it can be grown in all states in the country, but the major production of this spice is confined to Andhra Pradesh, Kerala, Tamil Nadu, Orissa and West Bengal out of which Andhra Pradesh is the leading turmeric producing State in the country. It occupies $35 \%$ of the land area contributing around $47 \%$ of total production in India. In Himachal Pradesh cultivation of this spice is being practiced on an area of 0.20 thousand hectares with in return production of 0.11 thousand tonnes per annum with productivity of 0.55 tonnes per hectares (National Horticulture Board, 2017).

In the age of precision agriculture approaches like soil testing provide an effective role to sustain the yield levels and soil health as its interpretations and recommendations relies on the local soil test crop response relationship data which provide the exact amount of nutrients to be applied. Besides this approach has much a limitation as it is only focused on the soil fertility classes instead of soil type, variety of crop and the climatic conditions prevailing in the area. The other concept of Soil test based fertilizer recommendation harmonizes the much debated needs i.e. Fertilize the soil versus Fertilize the crop for ensuring the real balance between the applied fertilizer nutrients and soil available nutrients. This nutrient application method helps to realize higher response and benefit: cost ratio over the traditional methods as the nutrients are applied in proportion to the magnitude of deficiency of a particular nutrient and the correction of that particular nutrient imbalance in soil (Rao and Srivastava, 2000).

In the past four decades micronutrient deficiencies have gained a special attention as most of the soils in India were found deficit in micronutrient status. The major reasons could be due to introduction of heavy nutrient feeder hybrids or due to various soil factors such as calcareousness, high $\mathrm{pH}$, low organic carbon, salinity and sodicity which reduce their availability to plants and ultimately lower the yield levels (Kulpapangkorna and Mai-leang, 2012; Safarzadeh et al., 2018). Approximately 60 per cent of the total cultivated area in India i.e.89.94 million hectare is considered acidic with $\mathrm{pH}$ less than 6.5 (Jehangir et al., 2013). Himachal Pradesh has 1.7 million hectares area under acidic soils favoring poor bases status and ultimately lowering the nutrient use efficiency. As a result the demand of these micronutrients for achieving higher yields increases and deficiencies are likely to become severe. An analysis of 2.00 lakh soil samples collected from different parts of the country revealed that there were predominant deficiency of $\mathrm{Zn}$ (36.5\%) followed by $\mathrm{B}(23.2 \%)$ and $\mathrm{Fe}$ (12.8\%) (Shukla and Behera, 2017). The deficiency of zinc is widespread in almost all 
the soils throughout the world followed by Fe, $\mathrm{Cu}$ and $\mathrm{B}$ (Hadler et al., 2007; Datta et al., 2017; Hnamte et al., 2018). Micronutrients application to soils is being less practiced as compared to macronutrients which supply substantial amounts of $\mathrm{N}, \mathrm{P}, \mathrm{K}$ and $\mathrm{S}$. inorganic fertilizers materials with organic manures were found to add frequently to the micronutrient pool in soils and improve nutrient use efficiency (Kamal and Yousuf, 2012; Rajeev Kumar et al., 2013). Moreover application of organic manures also contributes to the total content of micronutrients in surface soils. Keeping the above in view, the present work was undertaken to study the response of different organic and inorganic fertilizers to micronutrient availability in turmeric in an acid Alfisol.

\section{Materials and Methods}

A field experiment was conducted during Kharif season at the experimental farm of the Department of Soil Science, CSK Himachal Pradesh Krishi Vishvavidyalaya, Palampur, Himachal Pradesh, India. The study site was located at an elevation of about $1290 \mathrm{~m}$ amsl (Table 1). The experiment was laid out in a randomized block design (RBD) with eight treatments replicated thrice. The following treatments were incorporated in the study to compel on turmeric cv. Palam lalima.

$\mathrm{T}_{1}$ : Fertilizer application as per Farmer's practice

$\mathrm{T}_{2}$ : General recommended dose

$T_{3}$ : Soil test based

$T_{4}$ : Fertilizer based on STCR for yield target of 10 tha $^{-1}$

$T_{5}$ : Fertilizer based on STCR for yield target of 20 tha $^{-1}$

$\mathrm{T}_{6}$ : Fertilizer based on STCR for yield target of 30 tha $^{-1}$

$T_{7}$ : Fertilizer based on STCR for yield target of 40 tha $^{-1}$

$T_{8}$ : Absolute control
For seed purpose finger rhizomes were used and sown in raised bed plots of size $10 \mathrm{~m}^{2}$ $(5 \mathrm{~m} \times 2 \mathrm{~m})$ with the spacing of $30 \times 15 \mathrm{~cm}$. The major nutrients $\mathrm{N}, \mathrm{P}$ and $\mathrm{K}$ were supplemented through Urea, SSP (Single super phosphate) and MOP (Murate of potash). Besides farmyard manure was used as an organic manure. All the treatments received the application of FYM @ $5 \mathrm{t} \mathrm{ha}^{-1}$ except soil test based and absolute control. Fertilizer dose of 30: 60: $60 \mathrm{~kg} \mathrm{ha}^{-1}\left(\mathrm{~N}: \mathrm{P}_{2} \mathrm{O}_{5}\right.$ : $\mathrm{K}_{2} \mathrm{O}$ ) was practiced for recommended dose of fertilizer. Treatment pertaining of soil test based received the dose of fertilizers i.e. 30:45:75 $\left(\mathrm{N}: \mathrm{P}_{2} \mathrm{O}_{5}: \mathrm{K}_{2} \mathrm{O}\right)$ calculated on the basis of initial soil testing values. Farmer's practice was supplemented with $25 \%$ of the general recommended dose. Whereas, in targeted yield treatments the doses of fertilizers were calculated on equation based on STCR concept.

$\mathrm{FN}=1.30 \mathrm{~T}-0.58 \mathrm{SN}-0.08 \mathrm{ON}$, $\mathrm{FP}_{2} \mathrm{O}_{5}=0.45 \mathrm{~T}-1.00 \mathrm{SP}-0.10 \mathrm{OP}$, $\mathrm{FK}_{2} \mathrm{O}=1.78 \mathrm{~T}-1.21 \mathrm{SK}-0.10 \mathrm{OK}$

In above equations, $\mathrm{FN}, \mathrm{F}_{2} \mathrm{O}_{5}, \mathrm{~F} \mathrm{~K}_{2} \mathrm{O}$ are doses of $\mathrm{N}, \mathrm{P}_{2} \mathrm{O}_{5}$ and $\mathrm{K}_{2} \mathrm{O}$, respectively in $\mathrm{kg}$ $\mathrm{ha}^{-1}$. T was the yield target $\left(\mathrm{q} \mathrm{ha}{ }^{-1}\right)$. SN, SP and SK were soil available $\mathrm{N}, \mathrm{P}$ and $\mathrm{K}$ contents before sowing of the crop, respectively in $\mathrm{kg} \mathrm{ha}^{-1}$. Whereas, ON, OP and OK were $\mathrm{N}, \mathrm{P}$ and $\mathrm{K}$ supplied by FYM, respectively in $\mathrm{kg} \mathrm{ha}^{-1}$.

\section{Results and Discussion}

Effect of prescription based fertilizer application on DTPA extractable Fe, Mn, $\mathrm{Zn}$ and $\mathrm{Cu}$ in soil $\left(\mathrm{mg} \mathrm{kg}^{-1}\right)$ at the harvest of turmeric

Among all the treatments, highest DTPA extractable Fe content $\left(21.33 \mathrm{mg} \mathrm{kg}^{-1}\right)$ in soil was recorded under target yield based treatment $T_{7}$ and least $\left(15.92 \mathrm{mg} \mathrm{kg}^{-1}\right)$ in $T_{8}$ 
with the increase of 33.35 per cent among themselves (Table 2). In targeted yield treatments, $T_{6}$ and $T_{7}$ were found of great relevance by improving the $\mathrm{Fe}$ content of soil by 8.83 and 7.49 per cent over the treatments $\mathrm{T}_{4}$ and $\mathrm{T}_{5}$, respectively. Besides target based treatments, treatment $T_{2}$ was found superior over the $T_{3}$ and $T_{1}$ and marked a significant increase of 8.18 and 4.74 per cent, respectively. The Mn content the soil varied from $13.15 \mathrm{mg} \mathrm{kg}^{-1}$ in $\mathrm{T}_{8}$ to $18.58 \mathrm{mg} \mathrm{kg}^{-1}$ in $\mathrm{T}_{7}$ with an increase of 41.29 per cent and thus advocated the importance of target yield concept. Among the targeted yield treatments, $\mathrm{T}_{6}$ and $\mathrm{T}_{7}$ were found superior for holding maximum Mn content in the soil. Moreover, nutrients application through organic and inorganic sources under $\mathrm{T}_{2}$ treatment significantly increased the $\mathrm{Mn}$ content over the $T_{1}$ and $T_{3}$ to the tune of 1.6 and 28.86 per cent, respectively.

Furthermore, the maximum $\mathrm{Zn}$ content $(0.83$ $\mathrm{mg} \mathrm{kg}^{-1}$ ) was also recorded under $\mathrm{T}_{7}$ treatment and the least $\left(0.41 \mathrm{mg} \mathrm{kg} \mathrm{kg}^{-1}\right)$ under $\mathrm{T}_{8}$ treatment where negligible addition of inputs has been practiced and the increase was as high as 102.44 percent. While comparing different targeted yield treatments, $\mathrm{T}_{6}$ and $\mathrm{T}_{7}$ were found to be effective as they enhanced the $\mathrm{Zn}$ content of soil by 22.95 and 23.88 per cent over the $\mathrm{T}_{4}$ and $\mathrm{T}_{5}$, respectively (Table 2 ). Treatment $T_{2}$ also appeared with positive and significant results as it improved the $\mathrm{Zn}$ content of soil by 52.08 and 14.06 per cent over $T_{3}$ and $T_{1}$ treatments, respectively and thus showing the need of applying the recommended doses of nutrients. While DTPA extractable $\mathrm{Cu}$ content in the soil varied from $0.33 \mathrm{mg} \mathrm{kg}^{-1}$ in $\mathrm{T}_{8}$ to $0.62 \mathrm{mg} \mathrm{kg}$ 1 in $\mathrm{T}_{7}$ with per cent increase of 87.88. Targeted yield treatment $\mathrm{T}_{6}$ significantly builded up the $\mathrm{Cu}$ content by 7.27 over the $\mathrm{T}_{4}$ but later $\mathrm{T}_{4}$ treatment was found statistically at par with $\mathrm{T}_{5}$. Besides treatment $\mathrm{T}_{2}$ improved the soil $\mathrm{Cu}$ content by 39.02 and 5.56 per cent over the $\mathrm{T}_{3}$ and $\mathrm{T}_{1}$, respectively.

\section{Effect of prescription based fertilizer application on micronutrients concentration $\left(\mathrm{mg} \mathrm{kg}^{-1}\right)$ in turmeric rhizome and straw}

It is evident from the data presented in Table 3 that all the treatments significantly improved the micronutrients concentration in turmeric rhizome and straw over the $\mathrm{T}_{3}$ and $\mathrm{T}_{8}$. Targeted yield treatment $\mathrm{T}_{7}$ documented highest concentration of $\mathrm{Fe}$ in its rhizome (180 $\mathrm{mg} \mathrm{kg}^{-1}$ ) and straw (52.8 $\mathrm{mg} \mathrm{kg}^{-1}$ ) followed by $\mathrm{T}_{6}$ (Table 3 ). But later were found statistically at par with each other. Whereas, $\mathrm{T}_{5}$ treatment increased the $\mathrm{Fe}$ concentration by 3.55 per cent in rhizome and 15.83 per cent in straw over $\mathrm{T}_{4}$ which advocate the effectiveness of balanced and judicious application of fertilizers with organic manures. Application of fertilizers through recommended dose $\left(\mathrm{T}_{2}\right)$ provided satisfying results by significantly build up in the $\mathrm{Fe}$ concentration by 11.69 per cent in rhizome and 33.90 per cent in straw over soil test based $\left(\mathrm{T}_{3}\right)$ treatment. Whereas, the least concentration of $\mathrm{Fe}$ in rhizome and straw were recorded under $\mathrm{T}_{8}$ i.e. $126 \mathrm{mg} \mathrm{kg}^{-1}$ and $27.9 \mathrm{mg} \mathrm{kg}^{-1}$, respectively where negligible addition of nutrient sources was practiced.

Treatment $T_{7}$ in which fertilizers were applied as per targeted yield recorded highest $\mathrm{Mn}$ concentration of $92.9 \mathrm{mg} \mathrm{kg}^{-1}$ in rhizome and $47.7 \mathrm{mg} \mathrm{kg}^{-1}$ in its straw. Among the targeted yield treatments, $\mathrm{T}_{7}$ improved the $\mathrm{Mn}$ concentration by 13.02 per cent in rhizome and 21.68 per cent in straw over the $\mathrm{T}_{4}$. Application of RDF $\left(\mathrm{T}_{2}\right)$ resulted in significant increase in the $\mathrm{Mn}$ concentration in its rhizome and straw over the farmer's practice $\left(T_{1}\right)$ and soil test based $\left(T_{3}\right)$ treatments. Targeted yield treatment $\left(\mathrm{T}_{7}\right)$ resulted in highest $\mathrm{Zn}$ concentration of $51 \mathrm{mg}$ $\mathrm{kg}^{-1}$ in rhizome and $48.6 \mathrm{mg} \mathrm{kg}^{-1}$ in straw followed by $\mathrm{T}_{6}$. Among the different targeted yield treatments highest per cent variations were observed between $T_{4}$ and $T_{7}$ i.e. 30.76 
per cent in rhizome and 42.11 per cent in its straw. Application of RDF $\left(\mathrm{T}_{2}\right)$ significantly improved the $\mathrm{Zn}$ concentration by 21.05 per cent in rhizomes and 15.38 per cent in straw over soil test based treatment $\left(\mathrm{T}_{3}\right)$ (Table 3 ). Besides these application of fertilizers through farmer's practice $\left(\mathrm{T}_{1}\right)$ provided promising results over soil test based $\left(\mathrm{T}_{3}\right)$ in terms of higher $\mathrm{Zn}$ concentration in the rhizome and straw. Least concentrations of $\mathrm{Zn}$ were recorded under control treatment $\left(\mathrm{T}_{8}\right)$.

In terms of $\mathrm{Cu}$ concentration, the maximum concentration in rhizome (72 $\left.\mathrm{mg} \mathrm{kg}^{-1}\right)$ and straw (40.7 $\mathrm{mg} \mathrm{kg}^{-1}$ ) were recorded under $\mathrm{T}_{7}$ followed by $\mathrm{T}_{6}$, but later were found statistically at par with each other. Application of RDF $\left(\mathrm{T}_{2}\right)$ significantly enhanced its concentration by 30.61per cent in rhizome and 25.87 per cent in straw over soil test based treatment $\left(\mathrm{T}_{3}\right)$. Moreover, $\mathrm{T}_{1}$ also showed up significant improvement in the $\mathrm{Cu}$ concentration in rhizomes as well as in straw over $T_{3}$. Treatment $\mathrm{T}_{8}$ resulted in minimum $\mathrm{Cu}$ concentration i.e. $38 \mathrm{mg} \mathrm{kg}^{-1}$ in rhizome and $23.2 \mathrm{mg} \mathrm{kg}^{-1}$ in straw.

Effect of prescription based fertilizer application on $\mathrm{Fe}, \mathrm{Mn}, \mathrm{Cu}$ and $\mathrm{Zn}$ uptake $\left(\mathrm{g} \mathrm{ha}^{-1}\right)$ by turmeric

Highest Fe uptake by rhizome (1414 $\left.\mathrm{g} \mathrm{ha}^{-1}\right)$ and straw (84.5 $\mathrm{g} \mathrm{ha}^{-1}$ ) were recorded under target yield treatment $T_{7}$ followed by $T_{6}$ but later were found to be statistically at par with each other (Table 4). Likewise, application of RDF $\left(T_{2}\right)$ significantly increased the $\mathrm{Fe}$ uptake in rhizome by 36.3 per cent and 36.65 per cent over the $T_{1}$ and $T_{3}$, respectively. Whereas, treatments of farmer's practice $\left(\mathrm{T}_{1}\right)$, target yield treatment $\left(\mathrm{T}_{4}\right)$ and soil test based $\left(\mathrm{T}_{1}\right)$ were found statistically at par with each other. Least uptake of $\mathrm{Fe}$ by rhizome was recorded under $\mathrm{T}_{8}$ where negligible amounts of nutrients were applied.
In straw, application of $\operatorname{RDF}\left(\mathrm{T}_{2}\right)$ also provided satisfactory results by improving the Fe uptake by 44.94 per cent and 69.74 per cent over the $\mathrm{T}_{1}$ and $\mathrm{T}_{3}$, respectively. Among the targeted yield treatments, $\mathrm{T} 6$ enhanced the uptake by 44.03 per cent over $\mathrm{T}_{4}$. But later $\mathrm{T}_{6}$ was found statistically at par with $T_{7}$. Targeted yield treatment $\left(\mathrm{T}_{7}\right)$ increased the total Fe uptake by $1498 \mathrm{~g} \mathrm{ha}^{-1}$ but later it was found to be statistically at par with $T_{6}$. Besides application of RDF $\left(\mathrm{T}_{2}\right)$ improved the Fe uptake over $T_{1}$ and $T_{3}$ with per cent increase of 36.73 and 37.31 per cent, respectively. Whereas, the lowest total Fe uptake was recorded under $\mathrm{T}_{8}\left(261 \mathrm{~g} \mathrm{ha}^{-1}\right)$ treatment.

Targeted yield treatment $\left(\mathrm{T}_{7}\right)$ returned with highest Mn uptake of $696 \mathrm{~g} \mathrm{ha}^{-1}$ in rhizome and $77 \mathrm{~g} \mathrm{ha}^{-1}$ in straw but later was found statistically at par with $\mathrm{T}_{6}$. Moreover application of RDF $\left(\mathrm{T}_{2}\right)$ significantly increased the Mn uptake by 38.6 per cent cent over the $\mathrm{T}_{1}$ treatment. Among the targeted yield treatments, $\mathrm{T}_{5}$ significantly increased the Mn uptake by 41.3 per cent in rhizome over $\mathrm{T}_{4}$. Like $\mathrm{Mn}$ uptake in rhizome, $\mathrm{Mn}$ uptake by straw was minimum by $12.7 \mathrm{~g} \mathrm{ha}^{-1}$ in $\mathrm{T}_{8}$ and maximum by $77 \mathrm{~g} \mathrm{ha}^{-1}$ in $\mathrm{T}_{7}$. But later application of $T_{7}$ was found to be statistically at par with $\mathrm{T}_{6}$. The Mn uptake by straw in $\mathrm{T}_{2}$ increased significantly by 41.84 and 63.77 per cent over the $\mathrm{T}_{1}$ and $\mathrm{T}_{3}$, respectively. Whereas, among targeted yield treatments T6 marked a significant increase of 45.31per cent in Mn uptake over the $\mathrm{T}_{4}$. The total $\mathrm{Mn}$ uptake ranged from maximum of $773 \mathrm{~g} \mathrm{ha}^{-1}$ in $\mathrm{T}_{7}$ with least of $120 \mathrm{~g} \mathrm{ha}^{-1}$ in $\mathrm{T}_{8}$ treatment. but later treatments of $\mathrm{T}_{6}$ and $\mathrm{T}_{7}$ were found statistically at par with each other advocated no response of increased fertilizer application on Mn uptake by plant (Table 4). Fertilizer application through RDF $\left(\mathrm{T}_{2}\right)$ increased the total $\mathrm{Mn}$ uptake by 38.9 and 42.54 per cent over the $\mathrm{T}_{1}$ and $\mathrm{T}_{3}$, respectively. Whereas, targeted yield 
treatment $\left(\mathrm{T}_{6}\right)$ significantly improved the total Mn uptake by 41.8 per cent over the $\mathrm{T}_{5}$.But later treatment $\mathrm{T}_{5}$ was also found statistically at par with $\mathrm{T}_{1}, \mathrm{~T}_{3}$ in terms of total Mn uptake by plant.

Table.1 Physical and chemical properties of the initial soil sample $(0-15 \mathrm{~cm})$

\begin{tabular}{|c|c|}
\hline Soil property & Value \\
\hline \multicolumn{2}{|l|}{ A. Physical analysis } \\
\hline Water holding capacity ( per cent) & 52.4 \\
\hline \multicolumn{2}{|l|}{ Particle Size analysis } \\
\hline$\circ$ Sand $(\%)$ & 22.5 \\
\hline ○ $\operatorname{Silt}(\%)$ & 43.6 \\
\hline ○ $\operatorname{Clay}(\%)$ & 31.7 \\
\hline Textural class & Silty clay loam \\
\hline \multicolumn{2}{|l|}{ B. Chemical analysis } \\
\hline Soil pH & 5.35 \\
\hline Organic carbon $\left(\mathrm{g} \mathrm{kg}^{-1}\right)$ & 7.51 \\
\hline \multicolumn{2}{|l|}{ Available Nutrients $\left(\mathrm{kg} \mathrm{ha}^{-1}\right)$} \\
\hline ○ Nitrogen & 314 \\
\hline O Phosphorus & 30.7 \\
\hline ○ Potassium & 105 \\
\hline ○ Sulphur & 19.6 \\
\hline \multicolumn{2}{|c|}{ DTPA extractable micronutrients $\left(\mathrm{mg} \mathrm{kg}^{-1}\right)$} \\
\hline$\circ \mathbf{F e}$ & 18.4 \\
\hline ○ Mn & 15.4 \\
\hline$\circ \mathbf{Z n}$ & 0.57 \\
\hline$\circ \mathbf{C u}$ & 0.48 \\
\hline
\end{tabular}

Table.2 Effect of prescription based fertilizer application on DTPA extractable Fe, Mn, Zn and $\mathrm{Cu}$ in soil $\left(\mathrm{mg} \mathrm{kg}^{-1}\right)$ at the harvest of turmeric

\begin{tabular}{|c|l|l|l|l|}
\hline Treatment & Available Fe & Available Mn & Available Zn & Available Cu \\
\hline $\mathbf{T}_{\mathbf{1}}$ & 18.55 & 18.06 & 0.64 & 0.54 \\
\hline $\mathbf{T}_{\mathbf{2}}$ & 19.43 & 18.35 & 0.73 & 0.57 \\
\hline $\mathbf{T}_{\mathbf{3}}$ & 17.96 & 14.24 & 0.48 & 0.41 \\
\hline $\mathbf{T}_{\mathbf{4}}$ & 19.25 & 17.49 & 0.61 & 0.53 \\
\hline $\mathbf{T}_{\mathbf{5}}$ & 19.75 & 17.70 & 0.67 & 0.55 \\
\hline $\mathbf{T}_{\mathbf{6}}$ & 20.95 & 18.13 & 0.75 & 0.59 \\
\hline $\mathbf{T}_{\mathbf{7}}$ & 21.23 & 18.58 & 0.83 & 0.62 \\
\hline $\mathbf{T}_{\mathbf{8}}$ & 15.92 & 13.15 & 0.41 & 0.33 \\
\hline $\mathbf{S E} \mathbf{m} \mathbf{m}$ & 0.01 & 0.03 & 0.004 & 0.008 \\
\hline $\mathbf{C D}(\mathbf{P}=\mathbf{0 . 0 5})$ & 0.03 & 0.07 & 0.01 & 0.02 \\
\hline
\end{tabular}


Table.3 Effect of prescription based fertilizer application on $\mathrm{Fe}, \mathrm{Mn}, \mathrm{Zn}$ and $\mathrm{Cu}$ concentration $\left(\mathrm{mg} \mathrm{kg}^{-1}\right)$ in turmeric rhizome and straw

\begin{tabular}{|c|c|c|c|c|c|c|c|c|}
\hline \multirow[t]{2}{*}{ Treatment } & \multicolumn{2}{|c|}{ Fe } & \multicolumn{2}{|c|}{ Mn } & \multicolumn{2}{|c|}{$\mathbf{Z n}$} & \multicolumn{2}{|c|}{$\mathbf{C u}$} \\
\hline & Rhizome & Straw & Rhizome & Straw & Rhizome & Straw & Rhizome & Straw \\
\hline $\mathbf{T}_{1}$ & 162 & 41.7 & 82.5 & 37.3 & 42 & 36.2 & 57 & 32.3 \\
\hline $\mathbf{T}_{2}$ & 172 & 47.3 & 84.3 & 41.5 & 46 & 39 & 64 & 36 \\
\hline $\mathbf{T}_{\mathbf{3}}$ & 154 & 35.3 & 68.3 & 32 & 38 & 33.8 & 49 & 28.6 \\
\hline $\mathbf{T}_{4}$ & 169 & 41.7 & 82.2 & 39.2 & 39 & 34.2 & 60 & 34.2 \\
\hline $\mathbf{T}_{5}$ & 175 & 48.3 & 89.1 & 43.4 & 43 & 44.7 & 67 & 37.1 \\
\hline $\mathbf{T}_{6}$ & 179 & 51.3 & 91.0 & 46.5 & 49 & 48 & 70 & 39.5 \\
\hline $\mathbf{T}_{7}$ & 180 & 52.8 & 92.9 & 47.7 & 51 & 48.6 & 72 & 40.7 \\
\hline $\mathbf{T}_{8}$ & 126 & 27.9 & 61.9 & 27.7 & 30 & 24.9 & 38 & 23.2 \\
\hline SE $\mathbf{m} \pm$ & 0.60 & 0.64 & 0.19 & 1.13 & 0.33 & 0.52 & 0.86 & 0.52 \\
\hline $\mathrm{CD}(\mathrm{P}=0.05)$ & 1.44 & 1.62 & 0.49 & 2.75 & 0.84 & 1.31 & 2.09 & 1.29 \\
\hline
\end{tabular}

Table.4 Effect of prescription based fertilizer application on $\mathrm{Fe}, \mathrm{Mn}, \mathrm{Cu}$ and $\mathrm{Zn}$ uptake $\left(\mathrm{g} \mathrm{ha}^{-1}\right)$ by turmeric

\begin{tabular}{|c|c|c|c|c|c|c|c|c|c|c|c|c|}
\hline \multirow[t]{2}{*}{ Treatment } & \multicolumn{3}{|c|}{$\mathrm{Fe}$} & \multicolumn{3}{|c|}{ Mn } & \multicolumn{3}{|c|}{$\mathrm{Cu}$} & \multicolumn{3}{|c|}{ Zn } \\
\hline & Rhizome & Straw & Total & Rhizome & Straw & Total & Rhizome & Straw & Total & Rhizome & Straw & Total \\
\hline $\mathbf{T}_{1}$ & 444 & 26.7 & 471 & 210 & 23.9 & 234 & 156 & 20.6 & 176 & 115 & 23.2 & 139 \\
\hline $\mathbf{T}_{2}$ & 605 & 38.7 & 644 & 291 & 33.9 & 325 & 226 & 29.5 & 256 & 164 & 31.9 & 196 \\
\hline $\mathbf{T}_{3}$ & 446 & 22.8 & 469 & 207 & 20.7 & 228 & 142 & 18.5 & 160 & 111 & 21.8 & 133 \\
\hline $\mathbf{T}_{4}$ & 473 & 25.9 & 499 & 221 & 24.4 & 245 & 167 & 21.3 & 188 & 120 & 24.4 & 145 \\
\hline $\mathbf{T}_{5}$ & 1005 & 57 & 1062 & 482 & 51.2 & 533 & 386 & 43.7 & 429 & 279 & 52.7 & 332 \\
\hline$T_{6}$ & 1388 & 82.1 & 1470 & 681 & 74.4 & 756 & 546 & 63.2 & 610 & 398 & 76.7 & 475 \\
\hline $\mathbf{T}_{7}$ & 1414 & 84.5 & 1498 & 696 & 77 & 773 & 564 & 65.6 & 629 & 405 & 78.5 & 484 \\
\hline $\mathrm{T}_{8}$ & 248 & 12.8 & 261 & 108 & 12.7 & 120 & 136 & 10.7 & 147 & 61 & 11.5 & 72 \\
\hline SE $\mathbf{m} \pm$ & 24.37 & 1.01 & 26.13 & 13.94 & 1.78 & 15.51 & 11.08 & 1.00 & 11.41 & 8.31 & 0.93 & 7.98 \\
\hline $\mathrm{CD}(\mathrm{P}=0.05)$ & 62.3 & 2.52 & 62.22 & 34.84 & 4.56 & 37.84 & 28.41 & 2.64 & 28.52 & 20.27 & 2.38 & 19.94 \\
\hline
\end{tabular}

$\mathrm{Cu}$ uptake by turmeric rhizome varied from minimum of $136 \mathrm{~g} \mathrm{ha}^{-1}$ in $\mathrm{T}_{8}$ to the maximum of $564 \mathrm{~g} \mathrm{ha}^{-1}$ in $\mathrm{T}_{7}$. But later $\mathrm{T}_{7}$ treatment was found statistically at par with $\mathrm{T}_{6}$. Application of fertilizers and organic manures through framer's practice $\left(\mathrm{T}_{1}\right)$ did not significantly increased the $\mathrm{Cu}$ uptake over the $\mathrm{T}_{8}$ and hence were found at par with each other. Application of $\mathrm{RDF}\left(\mathrm{T}_{2}\right)$ increased the $\mathrm{Cu}$ uptake in rhizome by 44.87 and 59.15 per cent over the $T_{1}$ and $T_{3}$ treatments, respectively. Whereas, a significant increase of 41.45 per cent in $\mathrm{Cu}$ uptake by rhizome was recorded under $\mathrm{T}_{6}$ over $\mathrm{T}_{5}$ treatment. In straw, highest $\mathrm{Cu}$ uptake of $65.6 \mathrm{~g} \mathrm{ha}^{-1}$ was recorded under targeted yield treatment $\left(\mathrm{T}_{7}\right)$ followed by $\mathrm{T}_{6}\left(63.2 \mathrm{~g} \mathrm{ha}^{-1}\right)$ but later were found statistically at par. Whereas the per cent increase of 44.63 was observed between targeted yield treatments $\mathrm{T}_{6}$ and $\mathrm{T}_{5}$ and the increase was due to higher yield obtained which ultimately harvested appreciable amount of $\mathrm{Cu}$ from the soil. Apart from this, application of $\operatorname{RDF}\left(\mathrm{T}_{2}\right)$ increased the $\mathrm{Cu}$ uptake in straw by 43.20 and 59.4 per cent over the $T_{1}$ and $T_{3}$, respectively and the increase was due to application of FYM @ 05 $\mathrm{ha}^{-1}$ and higher yield obtained. Later treatments $\mathrm{T}_{1}, \mathrm{~T}_{3}$ and $\mathrm{T}_{4}$ were found statistically at par with each other. In terms of total $\mathrm{Cu}$ uptake, targeted yield treatment $\left(\mathrm{T}_{7}\right)$ excelled over all the other with highest value of $629 \mathrm{~g} \mathrm{ha}^{-1}$ followed by $\mathrm{T}_{6}\left(610 \mathrm{~g} \mathrm{ha}^{-1)}\right.$ but later were found statistically at par with each 
other. Least uptake of $\mathrm{Cu}$ by turmeric plant was associated to $\mathrm{T}_{8}\left(147 \mathrm{~g} \mathrm{ha}^{-1)}\right.$ as there was no fertilizer and FYM added. Besides application of RDF $\left(\mathrm{T}_{2}\right)$ increased the total $\mathrm{Cu}$ uptake by 45.46 and 60 per cent over the $T_{1}$ and $\mathrm{T}_{3}$ treatments, respectively.

Highest Zn uptake in rhizomes was recorded under $\mathrm{T}_{7}$ treatment $\left(405 \mathrm{~g} \mathrm{ha}^{-1}\right)$ followed by $\mathrm{T}_{6}$ (398 $\mathrm{g} \mathrm{ha}^{-1}$ ) but later were found statistically at par with each other. Application of RDF $\left(\mathrm{T}_{2}\right)$ provided promising results as it increased the $\mathrm{Zn}$ uptake by 42.60 and 47.74 per cent over the $T_{1}$ and $T_{3}$, respectively. Treatments pertaining of $T_{1}$ and $\mathrm{T}_{3}$ were found at par with $\mathrm{T}_{4}$. Among the targeted yield treatments, $\mathrm{T}_{6}$ recorded an increase of 42.65 per cent in $\mathrm{Zn}$ uptake by rhizome over $\mathrm{T}_{5}$ treatment. Whereas, $\mathrm{Zn}$ uptake in rhizome, its uptake in straw was also highest under $\mathrm{T}_{7}\left(78.5 \mathrm{~g} \mathrm{ha}^{-1}\right)$ treatment followed by $\mathrm{T}_{6}\left(76.7 \mathrm{~g} \mathrm{ha}^{-1}\right)$ but later both treatments were found statistically at par with each other. Application of RDF $\left(T_{2}\right)$ significantly increased the straw's Zn uptake by 37.5 and 46.33 per cent over the $T_{1}$ and $T_{3}$ treatment, respectively. Apart from this, treatments i.e. $\mathrm{T}_{1}$ and $\mathrm{T}_{3}$ were also found statistically at par with targeted yield treatment $\left(\mathrm{T}_{4}\right)$. In terms of total $\mathrm{Zn}$ uptake by turmeric plant, $\mathrm{T}_{7}$ exhibited highest uptake of $484 \mathrm{~g} \mathrm{ha}^{-1}$ which was later found at par with $\mathrm{T}_{6}\left(76.7 \mathrm{~g} \mathrm{ha}^{-1}\right)$ treatment. Whereas, the per cent increase in its total uptake by $\mathrm{T}_{2}$ ranged by 41.01 and 47.4 per cent over the $T_{1}$ and $T_{3}$, respectively. Moreover treatments of $\mathrm{T}_{1}$ and $\mathrm{T}_{3}$ were found statistically at par with targeted yield treatment $\left(\mathrm{T}_{4}\right)$. Targeted yield treatment $\left(\mathrm{T}_{6}\right)$ significantly enhanced the total $\mathrm{Zn}$ uptake by 43.07 per cent over the $\mathrm{T}_{5}$.

In conclusion the increased soil micronutrients concentration in targeted yield treatments and general recommended dose advocated the effectiveness of combined and judicious application of organic and inorganic amendments. Farmyard manure after decomposition released the micronutrients and ultimately recharges the soil micronutrient pool. Whereas, lower micronutrients concentration in soil attribute to poor inherent fertility status by less addition and more mining of these nutrients from the soil. The results were in agreement with the earlier studies reported by Singh (2002); Kumar et al., (2011); Dixit et al., (2010) and Singh (2011). Independent application of chemical fertilizers alone lead to reduced micronutrient content of the soil. Similar results were reported by Rao and Reddy (2005). Balanced and judicious use of fertilizers with farmyard manure increased the rhizome as well as straw yield levels. But such increase in growth pattern was not observed when fertilizers were applied beyond plant requirement and advocated the law of minimum which states that if all but one of the growth factors is present in adequate amounts, an increase in the quantity of this limiting factor will generally increase plant growth.

Almost similar findings were earlier reported by Gupta (1990); Rao et al., (1984); Majumdar et al., (2002) and Dixit et al., (2010). Lower uptake of micronutrient by turmeric crop could be explained by the lower yield obtained from poor soil fertility status. As uptake is multiply of yield and concentration of nutrient and if the yield is less, lesser will be the uptake of nutrient. Higher Phosphorus content in the soil lead to precipitation of micronutrients as metal phosphates. The results were in agreement with earlier studies reported by Gupta (1990); Singh (2011); Nandapure et al., (2011); Singh (2002) and Dixit et al., (2010).

\section{References}

Anonymous (2013) ICAR-Indian Institute of Spices Research, Kozhikode, Kerala. Anonymous (2015) Turmeric in Wikipedia, 
The Free Encyclopedia from https://en.wikipedia.org/w/index.php?ti tle $=$ Turmeric $\left(16^{\text {th }}\right.$ Jan 2019).

Datta SS, Chakraborty JC, Jana A, Debnath MK. Roy and Haque S. 2017. Effect of Different Micronutrients on Turmeric Variety Suranjana in Terai Region of West Bengal, India. International Journal of Current Microbiology and Applied Science 6:1471-82.

Gupta CR, Singh PN and Singh VK. 1990. Note on response of turmeric (Curcuma longa L.) to phosphorus in acidic soils. Vegetable Sciences 17:198-200.

Halder NK, Shill NC, Siddiky MA, Sarkar J and Gomes R. 2007. Response of Turmeric to Zinc and Boron Fertilization. Journal of Biological Science 7: 182-187.

Hnamte VR, Chatterjee, Lungmuana and Patra PK. 2018. Influence of boron and zinc nutrition on growth, yield and quality of turmeric (Curcuma longa L) in Gangetic alluvial soil of West Bengal. Journal of Crop and Weed 14:72-77.

Jehangir IA, Khan MH and Bhat ZA. 2013. Strategies of increasing crop production and productivity in problem soils. International Journal of Forestry, Soil and Erosion 2: 73-78.

Kamal MZU and Yousuf MN. 2012. Effect of organic manures on growth, rhizome yield and quality attributes of turmeric. The Agriculturists 10:16-22.

Kanwar KC. 2000. Turmeric- the wonder herb, The Tribune, Chandigarh (India) November, 22.

Kulpapangkorna W and Mai-leang S. 2012. Effect of plant nutrition on turmeric production. Procedia Engineering 32:166-71.

Kumar A, Dora J and Singh A. 2011. A review on spice of life Curcuma longa (Turmeric). Int $\mathrm{J}$ of Applied Biology and Pharmaceutical Technology 2:371-79.

Kumar S. 2004. Effect of chemical fertilizer and farmyard manure on yield and quality of garlic (Allium sativum L.) under mid hills of Himachal Pradesh. M. Sc Thesis, CSKHPKV, Palampur, India.

Majumdar B, Vektatsh MS and Kumar K. 2002. Effect of nitrogen and farmyard manure on yield and nutrient uptake of turmeric (Curcuma longa) and different forms of inorganic $\mathrm{N}$ build-up in an acidic Alfisol of Meghalaya. Indian Journal of Agricultural Sciences 72: 528-31.

Nandapure SP, Sonune BA, Glabhane VV, Katkar RN and Patil RT. 2011. Influence of long term fertilization on micronutrients availability, their uptake and productivity of turmeric-garlic sequence under semi- arid conditions on a Vertisol. Crop Research 42:35-39.

Rajeev K, Sandeep K, Ram J, Sanjeev K and Harnam S. 2013. Growth, yield and quality of turmeric (Curcuma longa L.) as influenced by organic manures. Agricultural ways 1:113-17.

Rao AS and Reddy KS. 2005. Emerging strategies for sustaining higher productivity and ensuring soil quality under intensive agriculture. Indian Journal of Fertility 1: 61-76.

Rao DV and Swamy GS. 1984. Studies on the effect of $\mathrm{N}, \mathrm{P}$ and $\mathrm{K}$ on growth, yield and quality of turmeric. South Indian Journal of Horticulture 32: 288-91.

Rao S and Srivastava S. 2000. Soil test based fertilizer use - a must for sustainable agriculture. Fertilizer News 45:25-38.

Ravindran PN, Ravindran K, Nirmal Babu, and Sivaraman K. 2007. Turmeric: the genus Curcuma; Medicinal and aromatic plants-- industrial profiles. CRC Press, Taylor \& Francis Group Boca Raton, FL. 236. 
Safarzadeh S, Kasmaei LS and Abadi ZA. 2018. Effect of organic substances on iron-release kinetics in a calcareous soil after basil harvesting. Journal of Serbian Chemical Society 83:941-52.

Shukla AK and Behera SK. 2017. Micronutrient Research in India: Retrospect and Prospects, preprints of seminar papers, SII-4/1-17, DOI:10.13140/RG.2.2. 20370. 76489.

Singh RD and Chauhan VS. 2002. Impact of inorganic fertilizers and organic manures on soil productivity under wheat-Ragi system. Journal of India Society of Soil Science 50: 62-63.
Singh SP. 2011. Effect of organic, inorganic and bio-fertilizer Azospirillum on yield and yield attributing characters of turmeric (Curcuma longa L.) cv.RAJENDRA SONIA. The Asian Journal of Horticulture 6: 16-18.

Srinivasan V, Thankamani CK, Kandiannan K, Zachariah TJ, Leela NK, Hamza S, Shajina O and Ansha O. 2016. Nutrient Management System in Turmeric: Effects on Soil Quality, Rhizome Yield and Quality. Industrial Crops and Products 85: 241-50.

\section{How to cite this article:}

Shubham, S.P. Dixit and Pathania, P. 2020. Studies on Combined Application of Organic and Inorganic Amendments on Micronutrients Availability to Turmeric in an Acid Alfisol. Int.J.Curr.Microbiol.App.Sci. 9(10): 233-242. doi: https://doi.org/10.20546/ijcmas.2020.910.030 